\title{
Pulmonary metastasis from endometrial carcinoma
}

\author{
Shinichi Miyazaki, ${ }^{1}$ Junzo Ishida, ${ }^{1}$ Keiji Nara, ${ }^{2}$ Takuya Ikeda ${ }^{1}$
}

'Shiritsu Yokkaichi Byoin, Yokkaichi, Japan

${ }^{2}$ Shiritsu Yokkaichi Byoin, Yokkaichi, Japan

\section{Correspondence to} Dr Shinichi Miyazaki, miyazaki.sin1@gmail.com

Accepted 14 February 2018
Check for updates

To cite: Miyazaki S, Ishida J, Nara K, et al. BMJ Case

Rep Published Online First: [please include Day Month Year]. doi:10.1136/bcr-2017223916

\section{DESCRIPTION}

A woman aged 69 years was referred to our department for the evaluation of a solitary pulmonary nodule. She had undergone total abdominal hysterectomy with bilateral salpingo-oophorectomy on diagnosis of endometrioid endometrial carcinoma (FIGO stage 1B, grade 2) 4 years ago. At that time, she received adjuvant treatment (six cycles of carboplatin and paclitaxel). After 3 years, chest CT scan revealed a nodule of $0.5 \mathrm{~cm}$ in diameter with cavitation in the right upper lobe of the lung (figure 1A). One year later, the pulmonary nodule increased in size $(1.3 \mathrm{~cm}$; figure $1 \mathrm{~B})$, and she underwent CT scanguided percutaneous transthoracic biopsy, which subsequently revealed potent oestrogen receptor-positive metastatic disease. She underwent wedge resection of the right upper lobe because the primary tumour site was controlled without an uncontrollable extrapulmonary disease. The resection margin was clear, and the nodule was well demarcated with a thin-walled cavity, measuring $1.5 \mathrm{~cm}$ in the largest dimension. The histological features were equivalent to those of the previous endometrial carcinoma (figure 1C). Furthermore, immunohistochemical analysis demonstrated positive oestrogen and progesterone receptors (figure 1D,E). The results of thyroid transcription factor- 1 and GATA-binding protein 3 were negative, and the Ki-67 proliferative index was $75 \%$. These findings suggested that the tumour favoured metastasis from endometrial carcinoma rather than the primary lung cancer. Three months

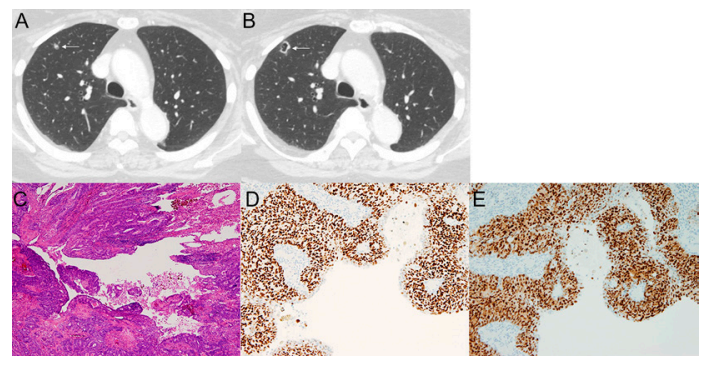

Figure 1 Chest CT scan (A) 3 years postoperatively and (B) 4 years postoperatively (arrow). (C) Microscopic image of the tumour $(H \& E, \times 100)$ and $(D, E)$ focal staining for oestrogen and progesterone receptor monoclonal antibodies at $\times 100$.

\section{Learning points}

- In patients with malignancy, a metastatic pulmonary tumour should be considered in the differential diagnosis of a solitary pulmonary nodule.

- A lung biopsy should be performed for preoperative diagnosis because it is difficult to differentiate from primary lung cancer in chest imaging.

after metasectomy, she exhibited recovery with no evidence of recurrence.

Endometrial carcinoma is the most common gynaecologic malignancy in high-income countries. Although the disease is confined to the uterus in a majority of patients, exhibiting a favourable prognosis, $13 \%$ of all endometrial cancers recur and $68 \%-100 \%$ of recurrences occur within 3 years. ${ }^{1}$ Typical metastatic sites include local pelvic recurrence, pelvic and para-aortic nodes, peritoneum and lungs. ${ }^{2}$ The usual pattern of pulmonary metastasis reveals multiple pulmonary nodules, and solitary pulmonary nodule with cavitation is rare. ${ }^{3}$ In this case, the CT finding of the tumour with solitary nodule and thinwalled cavity added to the difficulty in differentiating it from primary lung cancer in chest imaging.

Contributors SM cared for the patient, performed the clinical reasoning and wrote the article. JI and TI cared for the patient. $\mathrm{KN}$ made the pathological diagnosis and contributed microscopic pictures.

Funding This research received no specific grant from any funding agency in the public, commercial or not-for-profit sectors.

Competing interests None declared.

Patient consent Obtained.

Provenance and peer review Not commissioned; externally peer reviewed.

(C) BMJ Publishing Group Ltd (unless otherwise stated in the text of the article) 2018. All rights reserved. No commercial use is permitted unless otherwise expressly granted.

\section{REFERENCES}

1 Fung-Kee-Fung M, Dodge J, Elit L, et al. Follow-up after primary therapy for endometrial cancer: a systematic review. Gynecol Oncol 2006;101:520-9.

2 Kurra V, Krajewski KM, Jagannathan J, et al. Typical and atypical metastatic sites of recurrent endometrial carcinoma. Cancer Imaging 2013;13:113-22.

3 Bouros D, Papadakis K, Siafakas N, et al. Patterns of pulmonary metastasis from uterine cancer. Oncology 1996;53:360-3. 
Copyright 2018 BMJ Publishing Group. All rights reserved. For permission to reuse any of this content visit http://group.bmj.com/group/rights-licensing/permissions.

BMJ Case Report Fellows may re-use this article for personal use and teaching without any further permission.

Become a Fellow of BMJ Case Reports today and you can:

- Submit as many cases as you like

- Enjoy fast sympathetic peer review and rapid publication of accepted articles

Access all the published articles

- Re-use any of the published material for personal use and teaching without further permission

For information on Institutional Fellowships contact consortiasales@bmjgroup.com

Visit casereports.bmj.com for more articles like this and to become a Fellow 